\title{
The chiggerflea Hectopsylla pulex (Siphonaptera: Tungidae) as an ectoparasite of free-tailed bats (Chiroptera: Molossidae)
}

\author{
Júlia Lins Luz/ ${ }^{+}$, Luciana de Moraes Costa, Luiz Antonio Costa Gomes, \\ Carlos Eduardo Lustosa Esbérard
}

Laboratório de Diversidade de Morcegos, Universidade Federal Rural do Rio de Janeiro, CP 74507, 23890-000 Seropédica, RJ, Brasil

In the present study, we investigated the prevalence and intensity of Hectopsylla pulex infection in Molossus rufus and Molossus molossus, the parasite's choice of attachment site, and whether this host-parasite system varies with host size. Twenty-four bats were captured by hand from the roof of a house in Southeastern Brazil. M. rufus exhibited a prevalence of $71.4 \%$ and the mean intensity averaged 5 ectoparasites per bat. M. molossus exhibited a prevalence of $90 \%$, and the average mean intensity was 2.11 ectoparasites. The attachment sites were: ear, tragus, shoulder blade and tibia, anus, wing, axilla, mouth and dactylopatagium. A positive correlation was observed between the bats' weight and the number of fleas.

Key-words: body mass - infestation - prevalence - chiggerflea

Hectopsylla pulex (Haller, 1880) (= Rhynchopsyllus pulex Haller, 1880) (Méndez 1977, Hastriter \& Méndez 2000, Graciolli et al. 2008) is a burrowing chigger flea species (Siphonaptera: Tungidae). This species is an obligatory parasite of bats (Mammalia: Chiroptera). Females are usually found attached to the host in order to mature their eggs (Linardi \& Guimarães 2000), while males abandon their host after feeding. Hastriter and Mén$\operatorname{dez}(2000)$ captured females of $H$. pulex from bats, while males were only found associated with the guano of $\mathrm{Mo}$ lossus spp. (Molossidae), in Colombia and Panama.

Linardi and Guimarães (2000) reported the occurrence of this insect in Argentina, Bolivia, Brazil, Colombia, Chile, Ecuador, Peru and Venezuela. Twelve species of bats have already been reported to be infested by H. pulex (Tipton \& Machado-Allison 1972, Autino \& Claps 2000, Linardi \& Guimarães 2000, Esbérard 2001, Monteiro et al. 2005). Among bat species, there is a preference for Molossidae, since the parasite was only observed in specimens of Molossus molossus among a total of 66 individuals representing three families and seven species of different genera captured in artificial roosts in the municipality of Juiz de Fora, state of Minas Gerais (MG), Southeastern Brazil (Pallas 1766) (Netto 2001 apud Graciolli et al. 2008).

Esbérard (2001) is currently the only study to have analysed the prevalence and intensity of $H$. pulex in bats. Among 356 individuals of M. molossus captured from the roof of a house in the state of Rio de Janeiro (RJ), Southeastern Brazil, Esbérard (2001) collected 65

Financial support: FNMA, FAPERJ

+Corresponding author: julialinsluz@yahoo.com.br

Received 1 September 2008

Accepted 15 April 2009 fleas from 29 bats and determined a prevalence of $8.14 \%$ with fleas attached preferably to the bats' heads. Parasite intensity sorted by host gender was 1.57 in males and 2.87 in females, with a maximum number of six fleas on males and nine on females. Despite the existence of 176 other chiropterans belonging to four other species (including Molossus rufus E. Geoffroy, 1805) found in the same roost, the presence of this parasite was only observed in M. molossus.

Hosts that are vulnerable to parasitism are likely to be in a poor nutritional state. Alternatively, parasites may favour the exploitation of high-quality hosts, which would provide better single meals. Christe et al. (2003) demonstrated that parasite density was significantly higher on individual hosts in good nutritional condition when compared with poorly fed hosts.

Thus, the objectives of the present study were to investigate the prevalence and intensity of $H$. pulex in $M$. rufus and M. molossus, to determine the parasite's choice of attachment site and to determine whether this hostparasite system varies with bat condition.

\section{MATERIALS AND METHODS}

Since 2007, efforts have been made to characterise the biota of Praia das Neves (Southeastern Brazil) to support the Management Plan of "Lagartixa da Praia" (Liolaemus lutzae Mertens, 1938), and a campaign was carried out to analyse the local bat fauna. Located on the shore of the Itabapoana river, at the boundary of the states of Espírito Santo and RJ, Praia das Neves, Presidente Kenedy municipality $\left(21^{\circ} 05^{\prime} 56^{\prime \prime} \mathrm{S} 41^{\circ} 02^{\prime} 48^{\prime \prime} \mathrm{W}\right)$ still exhibits remnants of restinga (costal shrub land) and other typical vegetation of the Atlantic Forest ecoregion.

A mixed colony of M. molossus and M. rufus was found in a ceiling cavity of approximately $6 \mathrm{~m}^{2}$ in one of the houses in Praia das Neves. Bats of both species were roosting between the cistern and the wall, in a space that varies from $2-10 \mathrm{~cm}$. Both bat species had constant contact. 
From an estimated total of 30 individuals on 10 May 2008, 24 bats were captured by hand. Ectoparasites were removed with forceps and fixed in $92.4 \%$ alcohol. Bats were measured, weighed, marked with plastic bead necklaces with colored cylinders, and released at the same place. Bats were analysed to determine parasite prevalence, intensity (Margolis et al. 1982) and flea attachment site. Attachment sites were divided into nine categories: ear, tragus, shoulder blade, tibia, anus, wing, axilla, mouth and dactylopatagium. In order to calculate the mean intensity, non-infested individuals were not considered.

A Pearson correlation was used to test whether the variation of the body size and the number of ectoparasites were correlated, considering both bat species. For this analysis, we considered all individuals, including the non-infested ones. Statistical tests were performed using Systat 8.0 software.

\section{RESULTS}

Fourteen individuals of $M$. rufus ( 2 males and $12 \mathrm{fe}-$ males) exhibited a prevalence of $71.4 \%$ and an average mean intensity of 5 ectoparasites, with a total of 50 individuals of $H$. pulex (Table I). The number of fleas varied from 1-12 in females and from 6-7 in males.

Ten individuals of M. molossus (4 males and 6 females) exhibited a prevalence of $90 \%$ and an average mean intensity of 2.11 ectoparasites per bat, with a total of $19 \mathrm{H}$. pulex (Table I). The number of fleas varied from 1-2 in females and from 1-6 in males.

In both bat species, fleas were attached preferentially to the ear and tragus. Seven attachment sites were observed in M. rufus and four in M. molossus. Attachment sites were chosen in the following order of preference: ear, tragus, shoulder blade and tibia, anus, wing, axilla, mouth and dactylopatagium (Table II).

A significant positive correlation was observed between bat weight and the number of fleas found when both bat species were considered together $(\mathrm{r}=0.406, \mathrm{~N}$ $=24, \mathrm{p}=0.049$ ).

\section{DISCUSSION}

Most studies of $H$. pulex report only on its occurrence (Alarcón 2000, Autino \& Claps 2000, Monteiro et al. 2005). Only Esbérard (2001) has examined the prevalence and intensity in this host-parasite system, finding values much lower than those reported in the present study. The small number of individuals captured in Praia das Neves prevents further analysis; however, it is important to emphasise the high rate of prevalence and intensity found in this colony. Although our observations were based on a sole colony, the conditions observed here are unusual. The cohabitation between the two species is not typical and the inter-specific contact is even rarer. Our study likely represents the first report to find both species heavily parasitised with $H$. pulex.

Contrary to what was observed in RJ (Esbérard 2001) and MG (Netto 2001 apud Graciolli et al. 2008), we report a mixed bat colony where M. molossus is not the only infested species. A possible explanation is the higher bat density observed in the present study $\left(5.0 \mathrm{bats} / \mathrm{m}^{2}\right.$ of roost) compared to other previously reported densi-
TABLE I

Total of captures, number of bats infested, mean intensity and prevalence for both bat species captured in Praia das Neves

\begin{tabular}{lcc}
\hline & \multicolumn{2}{c}{ Host species } \\
\cline { 2 - 3 } & Molossus rufus & Molossus molossus \\
\hline Total of captures & 14 & 10 \\
Bats infested & 10 & 9 \\
Number of ectoparasites & 50 & 19 \\
Mean intensity & 5 & 2.11 \\
Prevalence (\%) & 71.43 & 90
\end{tabular}

TABLE II

Number of individuals of Hectopsylla pulex on different attachment sites on Molossus molossus and Molossus rufus in Praia das Neves

\begin{tabular}{lcc}
\hline Attachment sites & M. rufus & M. molossus \\
\hline Ear & 26 & 12 \\
Tragus & 15 & 5 \\
Shoulder blade & 3 & 0 \\
Tibia & 3 & 0 \\
Anus & 1 & 0 \\
Wing & 0 & 1 \\
Axilla & 1 & 0 \\
Mouth & 0 & 1 \\
Dactylopatagium & 1 & 0 \\
\hline TOTAL & 50 & 19 \\
\hline
\end{tabular}

ties $\left[0.3\right.$ bats $/ \mathrm{m}^{2}$ - considering the average number of bat captures and a roost with $150 \mathrm{~m}^{2}$ - Esbérard (2001) and unpublished observations]. This higher bat density may facilitate transmission between individual bats. A negative relationship between parasitism rate and roost area has already been described by Esbérard et al. (2005) in M. rufus infested by Hesperoctenes fumarius (Westwood, 1874).

As previously described, the parasites preferentially attach to the bat's head (ear and tragus). The attachment sites chosen by ectoparasites exhibit a thinner epidermis than other body parts, which probably makes the attachment easier (Marshall 1991). Alternatively, the ectoparasites may be more protected from bat grooming at those sites (Graciolli et al. 2008).

Although levels of parasitism can vary greatly among bats, little is known about how the characteristics of the hosts affect this variation. Two strategies of host choice are described in the literature and may occur in nature. These are the preference for a vulnerable host and the preference for a well-fed host (Zhang 1991, Criste et al. 2003, Presley 2004, Hawlena et al. 2005).

Ectoparasites did not respond consistently to host body size and the effect of host body size is still unknown. Pearce and O'Shea (2007) found that large adult brown bats had more ectoparasites than volant juveniles 
for most of the species analysed. Mite load and the condition of the bats were negatively correlated in a study by Lourenço and Palmeirim (2007) and the information available suggests that this may be due to an effect of parasitism. Heavier infestations of Streblidae parasites can be found in juvenile bats (Komeno \& Linares 1999, Bertola et al. 2005). Although usually attributed to a dispersal strategy due to the less frequent grooming activity performed by young bats, this effect may also be related to the smaller mass.

Patterson et al. (2008) did not find a relationship between prevalence and mean intensity with host body mass, distribution, or abundance, but the number of fly species was correlated with host body mass.

This study suggests that parasite density was significantly higher in larger bats. The circumstances under which the observations were made possibly favour the well-fed host strategy. Since that assumption is based on a sole colony, a larger sampling may be desirable to confirm our findings.

\section{ACKNOWLEDGEMENTS}

To AB Araujo, for support, AFPD Fernandes and EC Lourenço, for help in the field work, RM Silva, APF Prado and DS França, for assistance in laboratory work, to Katzenhaus Scientific Tradutions, for the translation into English and review, to two anonymous reviewers, who made several improvements, and to IBAMA, for sampling permits (SISBIO/ IBAMA n ${ }^{\circ}$ 10356-1).

\section{REFERENCES}

Alarcón ME 2000. Estado actual del conocimiento de los sifonápteros presentes en Chile (Insecta: Siphonaptera). Gayana 64: 1-17.

Autino AG, Claps GE 2000. Catalogue of the ectoparasitic insects of the bats of Argentina. Insecta Mundi 14: 192-209.

Bertola PB, Aires CC, Favorito SE, Graciolli G, Amaku M, Pintoda-Rocha R 2005. Bat flies (Diptera: Streblidae, Nycteribiidae) parasitic on bats (Mammalia: Chiroptera) at Parque Estadual da Cantareira, São Paulo, Brazil: parasitism rates and host-parasite associations. Mem Inst Oswaldo Cruz 100: 25-32.

Christe P, Giorgi MS, Vogel P, Arlettaz R 2003. Differential speciesspecific ectoparasitic mite intensities in two intimately coexisting sibling bat species: resource-mediated host attractiveness or parasite specialization? J Anim Ecol 72: 866-872.

Esbérard CEL 2001. Infestation of Rhynchopsyllus pulex (Siphonaptera: Tungidae) on Molossus molossus (Chiroptera) at Southeastern Brazil. Mem Inst Oswaldo Cruz 96: 1169-1170.

Esbérard CEL, Jesus AC, Motta AG, Bergallo HG, Gettinger D 2005. Hesperoctenes fumarius (Hemiptera: Polyctenidae) infesting Molossus rufus (Chiroptera: Molossidae) in Southeastern Brazil. J Parasitol 91: 467-470.
Graciolli G, Azevedo AA, Árzua M, Barros-Battesti DM, Linardi PM 2008. Artrópodos ectoparasitas de morcegos no Brasil. In S Pacheco, RV Marques, CEL Esbérard, Morcegos no Brasil, Armazém Digital, Porto Alegre, p. 115-135.

Hastriter MW, Méndez E 2000. A review of the flea genera Hectopsylla Frauenfeld and Rhynchopsyllus Haller (Siphonaptera: Pulicidae). Proc Entomol Soc Wash 103: 613-624.

Hawlena H, Abramsky Z, Krasnov BR 2005. Age-biased parasitism and density-dependent distribution of fleas (Siphonaptera) on a desert rodent. Oecologia 146: 200-208.

Komeno CA, Linhares AX 1999. Batflies parasitic on some phyllostomid bats in Southeastern Brazil: parasitism rates and host-parasite relationships. Mem Inst Oswaldo Cruz 94: 151-156.

Linardi PM, Guimarães LR 2000. Sifonápteros do Brasil, Museu de Zoologia USP, FAPESP, São Paulo, 291 pp.

Lourenço SI, Palmeirim JM 2007. Can mite parasitism affect the condition of bat hosts? Implications for the social structure of colonial bats. J Zool 273: 161-168.

Margolis L, Esch GW, Holmes JC, Kuris AM, Schad GA 1982. The use of ecological terms in parasitology (report of and ad hoc committee of the American Society of Parasitologists). J Parasitol 68: 131-133.

Marshall AG 1991. The ecology of ectoparasitic insects, Academic Press, New York, 445 pp.

Méndez E 1977. Mammalian-siphonapteran associations, the environment and biogegraphy of mammals of Southwestern Colombia. Quaest Entomol 13: 91-182.

Monteiro SG, Herrmann GP, Luchese FC, Mottin VD 2005. Primeiro registro de Rhynchopsyllus pulex (Siphonaptera: Tungidae) em Nyctinomops laticaudatus (Chiroptera: Molossidae) no Brasil. Cienc Rural 35: 956-957.

Netto Jr ER 2001. Ectoparasitos e hemoparasitos de algumas espécies de morcegos (Chiroptera) que utilizam abrigos artificiais no Município de Juiz de Fora - MG: observações preliminares, $\mathrm{PhD}$ Thesis, Universidade Federal de Juiz de Fora, Juiz de Fora, 48 pp.

Patterson BD, Dick CW, Dittmar K 2008. Parasitism by bat flies (Diptera: Streblidae) on neotropical bats: effects of host body size, distribution and abundance. Parasitol Res 103: 1091-1100.

Pearce RD, O'Shea TJ 2007. Ectoparasites in an urban population of big brown bats (Eptesicus fuscus) in Colorado. J Parasitol 93: 518-530.

Presley SJ 2004. Ectoparasitic assemblages of Paraguayan bats: ecological and evolutionary perspectives, $\mathrm{PhD}$ Thesis, Faculty of Texas Tech University, Texas, $346 \mathrm{pp}$.

Tipton VJ, Machado-Allison CE 1972. Fleas of Venezuela. Brigham Young Univer Sci Bul 17: 1-115.

Zhang Z 1991. Parasitism of Acyrthosiphon pisum by Allothrombium pulvinum (Acariformes: Trombidiidae): host attachment site, host size selection, superparasitism and effect on host. Exp Appl Acarol 11: 137-147. 